\title{
Analisis Pergeseran Koseismik Gempa Sianok Tahun 2007 Berdasarkan Data Pengamatan GPS Tahun 1993-2007 dan Efek terhadap SRGI 2013
}

\author{
JONI EFENDI, KOSASIH PRIJATNA, IRWAN MEILANO
}

\author{
Program Studi Teknik Geodesi dan Geomatika \\ Institut Teknologi Bandung \\ Email: joni.efendi@big.go.id
}

\begin{abstract}
ABSTRAK
Tumbukan miring Lempeng Eurasia dengan Lempeng Indo-Australia membentuk zona subduksi di bagian barat Pulau Sumatra dan sejumlah segmen sesar di darat Pulau Sumatra. Zona subduksi dan segmen sesar yang terbentuk aktif bergerak sehingga sering menimbulkan gempa bumi di wilayah tersebut. Semenjak diberlakukannya Sistem Referensi Geospasial Indonesia 2013 (SRGI 2013) sebagai referensi tunggal dalam aktivitas pemetaan di Indonesia, maka perubahan posisi kerangka referensi koordinat sebagai fungsi waktu akibat dinamika bumi perlu diperhitungkan. Dengan terjadinya dua gempabumi yang berurutan pada tanggal 6 Maret 2007 di wilayah Danau Singkarak Sumatra Barat, akan menimbulkan deformasi koseismik yang dapat mempengaruhi SRGI2013. Dalam penelitian ini dilakukan analisis untuk menentukan model koseismik gempabumi Sianok yang paling sesuai dan sejauh mana dampaknya pada SRGI 2013. Berdasarkan hasil analisis terhadap nilai residual hasil validasi dengan koseismik pada 11 titik pengamatan GPS dapat disimpulkan bahwa model koseismik dari gempabumi Sianok adalah model koseismik menggunakan data parameter gempa dari Global CMT dengan residual misfit $47.5 \mathrm{~mm}$. Secara umum, pola kosesimik gempabumi Sianok mendeskripsikan mekanisme gempabumi sesar geser. Nilai kosesimik terbesar terjadi pada titik KACA dan K108, yaitu 135,43 mm dan 84,74 mm. Besarnya koseismik gempabumi Sianok tidak berpengaruh terhadap peta dengan skala 1: 1000, akan tetapi akan mempengaruhi nilai koordinat Jaring Kontrol Geodesi (JKG) yang berada di sekitar daerah gempa, sehingga perlu adanya pemutakhiran koordinat dari JKG.
\end{abstract}

Kata kunci: Gempabumi Sianok, GPS, Deformasi Koseismik, SRGI2013.

\begin{abstract}
The oblique movement of Eurasian Plate towards Indo-Australian Plate create subduction zone in the western part of Sumatra Island and some faults on the mainland of Sumatra. These subduction zone and faults actively produce some earthquakes. Since we used the Geospatial Reference System of Indonesia 2013 (SRGI 2013) as one reference on mapping activities in Indonesia, coordinate changes as a function of time caused by earthquake cycle need to be calculated. There are two earthquakes that had been occurred on March 6, 2007 in Singkarak Lake area which affected the SRGI 2013. We analyzed the data to estimate the coseismic model of Sianok earthquake and the impact to the SRGI 2013. The residual from the coseismic model by including 11 GPS displacements shows that the coseismic model of Sianok earthquake is a model that used earthquake parameters from Global CMT with the misfit of $47.5 \mathrm{~mm}$. Overall, this coseismic pattern shows the shear mechanism. The largest displacements are on KACA and K108 sites, that are $135.43 \mathrm{~mm}$ and $84.74 \mathrm{~mm}$ respectively. The coseimic of Sianok earthquake does not affect a map with scale of 1:1000, but affect the Geodetic Control Network in this area. From this analysis, we conclude that we need to update our Geodetic Control Network.
\end{abstract}

Keywords: Sianok Earthquake, GPS, Coseismic Deformation, SRGI2013. 


\section{PENDAHULUAN}

Pulau Sumatera terletak pada lempeng Eurasia yang bergerak dan berinteraksi secara konvergen dengan lempeng Indo-Australia. Tumbukan miring antara kedua lempeng tersebut membentuk zona subduksi di bagian barat pulau Sumatra dengan kecepatan $50 \mathrm{~mm} / \mathrm{yr}$ sampai dengan $70 \mathrm{~mm} / \mathrm{yr}$ (Prawirodirdjo dkk., 1997) dan membentuk sejumlah segmen sesar yang membentang sepanjang pulau Sumatera dari Aceh di utara sampai dengan palung sunda di selatan dengan total panjang sekitar $1900 \mathrm{~km}$. Sesar Sumatra merupakan sesar strike-slip berarah dekstral dengan kecepatan berkisar dari $2.5 \mathrm{~mm}$ sampai dengan $30 \mathrm{~mm}$ pertahun (Sieh dan Natawidjaja, 2000). Akibat dari kondisi ini menyebabkan wilayah sumatera rawan terhadap gempabumi, terlihat dari catatan sejarah selama kurun 200 tahun tercatat telah terjadi puluhan gempa besar pada zona sesar Sumatera (Natawidjaja dkk., 2007).

Pembangunan Jaring Kontrol Horisontal secara sistematik di Indonesia telah dimulai dari zaman pemerintahan Hindia Belanda (1862), yang dilakukan untuk keperluan kontrol posisi horizontal pekerjaan pemetaan. Dalam perkembangannya dari tahun 1862 sampai dengan tahun 1962 dibangun sekitar 1026 titik triangulasi. Posisi Jaring Triangulasi karena keterbatasan teknologi, koordinatnya dihitung dalam beberapa datum berbeda. Pada tahun 1974 pertama kali dibangun jaring kontol horizontal dengan teknologi satelit Doppler, sampai tahun 1986 telah dibangun sekitar 966 titik. Posisi titik Doppler koordinatnya dihitung dalam datum ID74 (Indonesia Datum 1974) (Subarya, 2010).

Pada tahun 1989 Bakosurtanal menyelenggarakan jaring kontrol horizontal untuk keperluan pemantauan geodinamika di Sumatera dengan teknologi satelit GPS, kemudian dari tahun 1992 jaring kontrol GPS ini diperluas ke bagian timur Indonesia sampai ke Irian Jaya. Posisi jaring kontrol horizontal dengan GPS koordinatnya dihitung dalam datum DGN 95 (Datum Geodesi Nasional 1995) (Abidin, 2011).

Ketiga jaring kontrol ini menggunakan datum statik, dimana pada datum statik nilai koordinat titik kontrol ditetapkan selalu sama sepanjang waktu, sehingga untuk wilayah Indonesia yang mempunyai tingkat kegempaan yang relatif tinggi serta tatanan tektonik yang relatif kompleks, seiring waktu berjalan, keakurasian koordinat titik kontrol akan terdegradasi. Perkembangan teknologi penentuan posisi dengan satelit Global Navigation Satellite System (GNSS) yang saat ini semakin berkembang telah meningkatkan keakurasian koordinat hasil penentuan posisi hingga fraksi milimeter, sehingga dapat digunakan untuk mendeteksi terjadi deformasi akibat fenomena dinamika bumi.

Pada tanggal 27 Oktober 2013, Badan Informasi Geospasial (BIG) sebagai penyelenggara informasi geospasial nasional memberlakukan sistem referensi geospasial tunggal dengan nama Sistem Referensi Geospasial Indonesia 2013 (SRGI 2013) yang tertuang dalam Peraturan Kepala BIG No. 15 tahun 2013. Nilai koordinat kerangka referensi koordinat SRGI 2013 terdefinisi pada epok 2012 dan terikat pada kerangka referensi global International Terrestrial Reference Frame 2008 (ITRF 2008) serta menggunakan elipsoid referensi World Geodetic System 1984 (WGS 1984) sebagai datum geodetik dan dilengkapi dengan model deformasi (model vektor perubahan nilai koordinat suatu titik sebagai fungsi dari waktu). SRGI 2013 telah memperhitungkan komponen perubahan posisi kerangka referensi koordinat sebagai fungsi waktu, sehingga kejadian-kejadian deformasi baik deformasi akibat pergerakan lempeng tektonik maupun gempabumi perlu diperhitungkan agar model deformasi dapat terpelihara dengan baik. 
Pada tanggal 6 Maret 2007 terjadi dua gempa cukup besar dalam periode dua jam di wilayah Danau Singkarak Sumatera Barat yang berpusat di segmen Sumani dan Sianok (Natawidjaja dkk., 2007). Gempa pertama terjadi pada jam 10:49:39 AM waktu setempat dengan kekuatan Mw 6.4 pada lokasi $0,512^{\circ} \mathrm{LS}, 100,524^{\circ} \mathrm{BT}$ (segmen Sumani) dan gempa kedua terjadi pada jam 12:49:28 PM waktu setempat dengan kekuatan Mw 6.3 pada lokasi 0,49 ${ }^{\circ} \mathrm{LS}, 100,52^{\circ} \mathrm{BT}$ (segmen Sianok). Kejadian gempabumi di daerah Danau Singkarak, bukan hanya menyebabkan korban jiwa dan kerusakan infrastruktur dan bangunan tapi juga akan mempengaruhi SRGI 2013.

Tujuan dari penelitian ini adalah untuk mendapatkan model deformasi koseismik terbaik yang diakibatkan oleh gempa Sianok dan dampaknya pada SRGI 2013. Untuk mencapai tujuan tersebut, ruang lingkup penelitian mencakup hal-hal sebagai berikut:

1) Mengestimasi deret waktu koordinat titik pengamatan Global Positioning System (GPS) yang ada disekitar lokasi gempa dalam ITRF 2008. Jumlah total stasiun GPS yang digunakan dalam penelitian ini adalah 11 stasiun yang diamati dari tahun 1993 sampai tahun 2007. Sebaran stasiun GPS tersebut dapat dilihat pada Gambar 2.

2) Mengestimasi koseismik gempabumi sianok dari deret waktu koordinat titik pengamatan GPS.

3) Mengestimasi koseismik gempabumi sianok berdasarkan parameter gempabumi yang didapat dari Global Centroid Moment Tensor (CMT) (www.globalcmt.org) dengan melakukan perubahan lokasi pusat gempa agar mendekati koseismik dari pengamatan GPS.

4) Melakukan pemodelan deformasi koseismik Gempa Sianok wilayah Sumatera Barat berdasarkan data Global CMT yang dimodifikasi.

5) Menganalisis pengaruh koseismik gempa Sianok terhadap SRGI 2013.

\section{METODOLOGI}

\subsection{Estimasi Koseismik Dari Data GPS}

Estimasi pergeseran koseismik akibat peristiwa gempabumi dilakukan bersamaan dengan tahapan estimasi vektor kecepatan dari data deret waktu koordinat titik GPS. Estimasi deformasi koseismik dari deret waktu koordinat GPS menggunakan persamaan berikut (Nikolaidis, 2002):

$$
\begin{aligned}
y\left(t_{i}\right)= & a+b t_{i}+c \sin \left(2 \pi t_{i}\right)+d \cos \left(2 \pi_{t} i\right)+e \sin \left(4 \pi t_{i}\right) \\
& +f \cos \left(4 \pi t_{i}\right)+\sum_{j=1}^{n_{g}} g_{j} H\left(t_{i}-T_{g j}\right)+v_{i}
\end{aligned}
$$

dengan $y(t i)$ merupakan koordinat GPS deret waktu dalam epok pengamatan $t_{i}$ untuk $i=1 \ldots$ $\mathrm{n}, \mathrm{H}$ adalah fungsi Heaviside step, koefisien a adalah nilai menengah dari yt dan b merupakan posisi dan kecepatan dari stasiun, koefesien c dan e merupakan sinus amplitude dari gerakan periodik tahunan/semi tahunan, koefisien $\mathrm{d}$ dan $\mathrm{f}$ merupakan cosinus amplitude dari gerakan periodik setengah-tahunan, parameter berikutnya merupakan koreksi untuk setiap bilangan $n_{\mathrm{g}}$ offset dengan besaran $\mathrm{g}$ pada epok $\mathrm{T}_{\mathrm{g}}$. Kesalahan pengamatan $\mathrm{v}$ diasumsikan bersifat berdiri sendiri (tidak mempengaruhi), terdistribusi secara identik, dan bersifat acak dengan $E(v)=0$.

Persamaan (1) merupakan persamaan untuk mengestimasi vektor kecepatan linear dari data stasiun kontinu GPS. Apabila data yang digunakan adalah data GPS berkala maka persamaan (1) dapat disederhanakan menjadi persamaan berikut: 


$$
y\left(t_{i}\right)=a+b t_{i}+\sum_{j=1}^{n_{g}} g_{j} H\left(t_{i}-T_{g j}\right)+v_{i}
$$

Pada rumus (2) koefisien a dan b merupakan posisi dan kecepatan dari titik pengamatan GPS.

\subsection{Pemodelan Koseismik Dari Parameter Geometri Gempabumi}

Estimasi deformasi koseismik menggunakan data parameter gempabumi menggunakan spherical layered model (Pollitz, 1996). Deformasi permukaan dihitung dengan model bumi dari Dziewonski dan Anderson (1981), dimana koefisien harmonik yang digunakan adalah $1^{\circ}$ sampai $1500^{\circ}$. Pollitz (1996) menggunakan solusi persamaan keseimbangan statik (static equilibrium) yang direpresentasikan sebagai super-posisi komponen spheroidal dan toroidal yang bergantung dengan derajat koefisien spherical dan moment tensor. Deformasi permukaan dapat direpresentasikan dalam bentuk spherical dan toroidal model dengan persamaan berikut:

$$
\begin{gathered}
S_{l}^{m(S)}(r, \theta, \phi)=\left[y_{1}^{\operatorname{lm}(S)}(r) \hat{\mathbf{r}}+y_{3}^{\operatorname{lm}(S)}(r) \nabla_{1}\right] Y_{l}^{m}(\theta, \phi) \\
S_{l}^{m(T)}(r, \theta, \phi)=-y_{1}^{\operatorname{lm}(S)}(r) \hat{\mathbf{r}} \times \nabla_{1} Y_{l}^{m}(\theta, \phi)
\end{gathered}
$$

Persamaan (3) untuk deformasi permukaan dalam spheroidal dan persamaan (4) untuk deformasi permukaan dalam toroidal.

STATIC 1D (Pollitz, 1996) merupakan perangkat lunak untuk menghitung deformasi permukaan dari data parameter gempabumi yang menggunakan konsep dalam Pollitz (1996). STATIC 1D menghitung deformasi di permukaan dengan menggunakan konsep penjalaran gelombang di kerakbumi yang berlapis. Lebih dari $20 \%$ kesalahan terjadi apabila layer struktur bumi diabaikan dalam hitungan deformasi permukaan. Nilai ini diperoleh dari hasil perbandingan deformasi permukaan dengan metode bumi homogen dan tidak homegen (layer) (Pollitz, 1996).

STATIC 1D sangat cocok untuk menghitung pergeseran stastik di permukaan Bumi dalam skala lokal, regional, maupun global. Geometri bidang gempa yang digunakan sebagai input untuk perangkat lunak STATIC 1D terlihat seperti pada Gambar 1. 


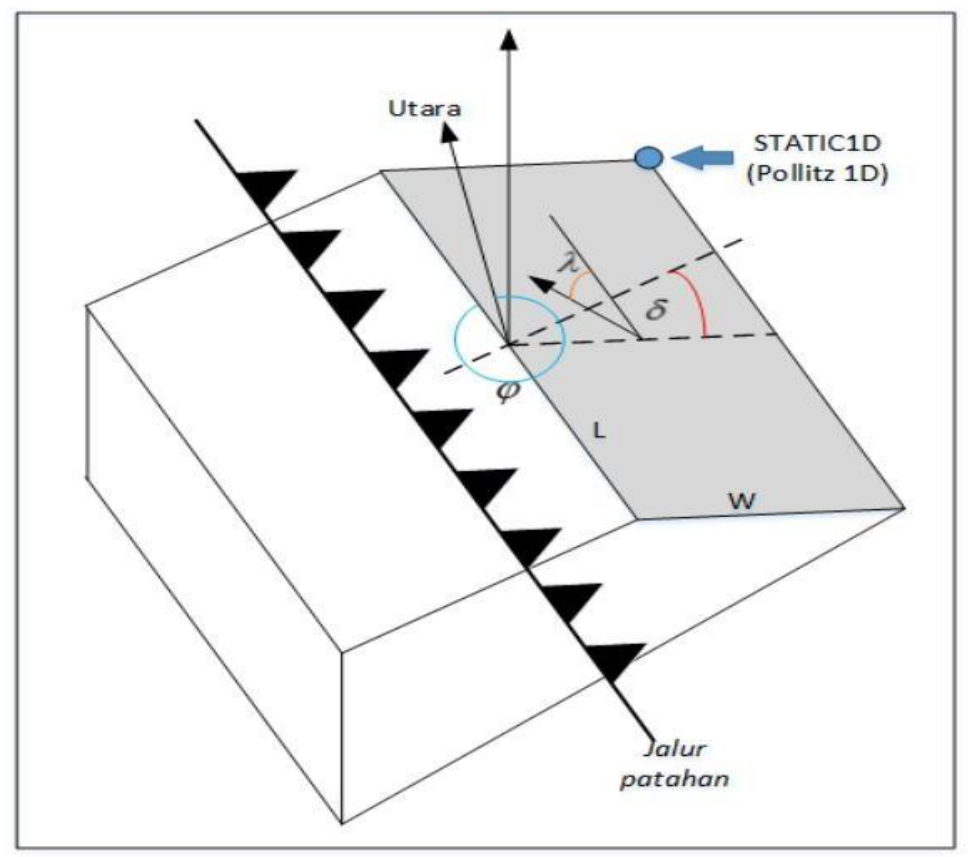

Gambar 1. Geometri gempabumi dan titik referensi untuk pemodelan STATIC1D; $\mathbf{j}$ adalah arah jalur patahan dari utara (strike); $\mathbf{d}$ adalah sudut kemiringan patahan dari horizontal (dip); I adalah arah slip pada bidang gempa (rake); L adalah panjang bidang gempa; $\mathbf{W}$ adalah lebar bidang gempa

Pergeseran titik di permukaan bumi dihitung dari geometri gempabumi dimana titik referensi bidang gempa terletak di pojok bawah bidang gempa yang terdekat dengan arah strike. Nilai slip dari setiap patch digunakan sebagai input untuk perangkat lunak STATIC 1D.

\subsection{Data Penelitian}

Data GPS yang digunakan diperoleh dari hasil survei GPS berkala yang dilakukan oleh Badan Informasi Geospasial (BIG) dan data GPS stasiun International GNSS Service (IGS), serta data parameter gempa dari global CMT.

1) Stasiun Pengamatan GPS Berkala, Badan Informasi Geospasial (BIG)

Data pengamatan GPS berkala yang digunakan pada penelitian ini diamati pada tahun 1993 sampai 2007, sebanyak 11 titik. Seperti pada Tabel 1 dan Gambar 2. 


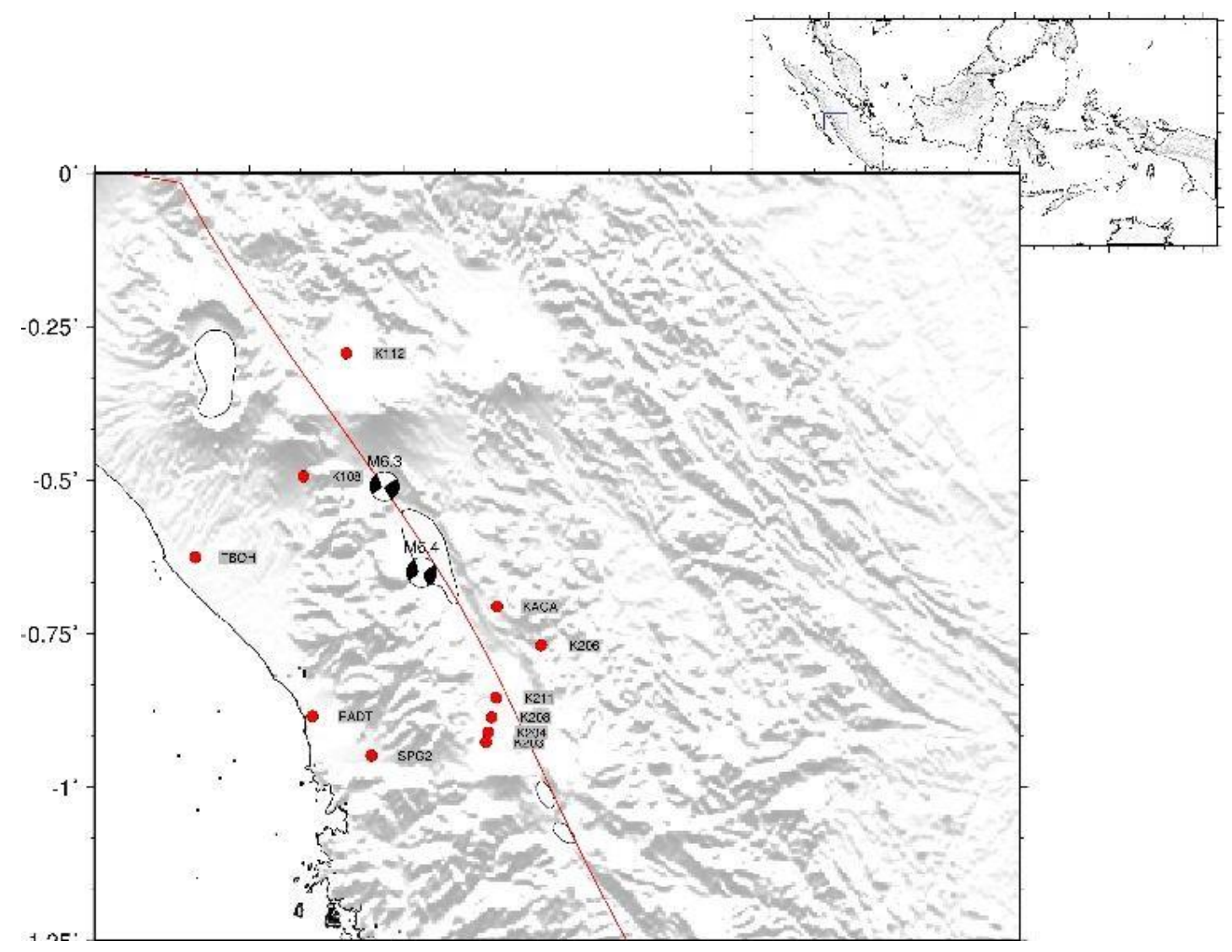

Gambar 2. Distribusi titik GPS berkala BIG

Tabel 1. Ketersediaan data pengamatan GPS berkala BIG

\begin{tabular}{cllcccccc}
\hline \multirow{2}{*}{ No } & $\begin{array}{l}\text { Nama } \\
\text { Stasiun }\end{array}$ & \multirow{2}{*}{ Lokasi } & \multicolumn{7}{c}{ Tahun } \\
\cline { 3 - 8 } & K108 & Padang Pariaman & $\mathbf{1 9 9 3}$ & $\mathbf{1 9 9 7}$ & $\mathbf{2 0 0 1}$ & $\mathbf{2 0 0 5}$ & $\mathbf{2 0 0 6}$ & $\mathbf{2 0 0 7}$ \\
\hline 1 & Kab. Agam & $\mathrm{x}$ & - & - & - & $\mathrm{x}$ & $\mathrm{x}$ \\
\hline 2 & K112 & Solok & $\mathrm{x}$ & - & - & - & $\mathrm{x}$ & $\mathrm{x}$ \\
\hline 3 & K203 & Solok & $\mathrm{x}$ & - & - & - & $\mathrm{x}$ & $\mathrm{x}$ \\
\hline 4 & K204 & Solok & $\mathrm{x}$ & - & - & - & $\mathrm{x}$ & $\mathrm{x}$ \\
\hline 5 & K206 & Solok & $\mathrm{x}$ & - & - & - & $\mathrm{x}$ & $\mathrm{x}$ \\
\hline 6 & K208 & Solok & $\mathrm{x}$ & - & - & - & $\mathrm{x}$ & $\mathrm{x}$ \\
\hline 7 & K211 & Solok & $\mathrm{x}$ & - & $\mathrm{x}$ & $\mathrm{x}$ & - & $\mathrm{x}$ \\
\hline 8 & KACA & Batusangkar & $\mathrm{x}$ & $\mathrm{x}$ & $\mathrm{x}$ & $\mathrm{x}$ & $\mathrm{x}$ & $\mathrm{x}$ \\
\hline 9 & PADT & Kota Padang & $\mathrm{x}$ & $\mathrm{x}$ & $\mathrm{x}$ & $\mathrm{x}$ & $\mathrm{x}$ & $\mathrm{x}$ \\
\hline 10 & SPG2 & Kota Padang & $\mathrm{x}$ & & $\mathrm{x}$ & $\mathrm{x}$ & $\mathrm{x}$ & $\mathrm{x}$ \\
\hline 11 & TBOH & Pariaman & & & & &
\end{tabular}

Keterangan: X (Data tersedia) dan - (Data tidak tersedia).

2) Stasiun International GNSS Service (IGS)

Pada penelitian ini, digunakan 9 stasiun GPS IGS dimana ketersediaan data stasiun GPS IGS untuk setiap stasiun pengamatan GPS dari tahun 1993 sampai tahun 2007 ditunjukkan pada Tabel 2. 
Tabel 2. Ketersediaan data stasiun GPS IGS

\begin{tabular}{|c|c|c|c|c|c|c|c|c|}
\hline \multirow{2}{*}{ No } & \multirow{2}{*}{$\begin{array}{l}\text { Nama } \\
\text { Stasiun }\end{array}$} & \multirow{2}{*}{ Lokasi } & \multicolumn{6}{|c|}{ Tahun } \\
\hline & & & 1993 & 1994 & 2001 & 2005 & 2006 & 2007 \\
\hline 1 & IISC & Bangalore, India & $x$ & $x$ & $x$ & $x$ & $x$ & $\mathrm{x}$ \\
\hline 2 & CUSV & Patumwan, Thailand & $x$ & $x$ & $x$ & $\mathrm{x}$ & $x$ & $\mathrm{x}$ \\
\hline 3 & PIMO & Manila, Filipina & $x$ & $x$ & $x$ & $x$ & $x$ & $x$ \\
\hline 4 & DARW & Darwin, Australia & $\mathrm{x}$ & $x$ & $\mathrm{x}$ & $\mathrm{x}$ & $\mathrm{x}$ & $\mathrm{x}$ \\
\hline 5 & KARR & Karratha, Australia & $\mathrm{x}$ & $x$ & $\mathrm{x}$ & $\mathrm{x}$ & $\mathrm{x}$ & $x$ \\
\hline 6 & COCO & Pulau Coco, Australia & $x$ & $x$ & $x$ & $x$ & $x$ & $x$ \\
\hline 7 & XMIS & Christmas, Australia & $x$ & $\mathrm{x}$ & $x$ & $x$ & $x$ & $x$ \\
\hline 8 & DGAR & Diego Garcia, UK & $x$ & $x$ & $x$ & $x$ & $x$ & $x$ \\
\hline 9 & GUAM & Dededo, Guam & $x$ & $x$ & $x$ & $x$ & $x$ & $\mathrm{x}$ \\
\hline
\end{tabular}

3) Data parameter gempabumi Global CMT

Data parameter gempabumi Sumani dan Sianok yang terjadi pada tanggal 6 Maret 2007 dari global CMT catalog adalah sebagai berikut (Tabel 3).

Tabel 3. Data parameter gempabumi dari global CMT

\begin{tabular}{lcccccccccc}
\hline $\begin{array}{l}\text { Tanggal } \\
{[\mathrm{y} / \mathrm{m} / \mathrm{d}]}\end{array}$ & $\begin{array}{c}\text { Buj } \\
\left.{ }^{0}\right]\end{array}$ & $\begin{array}{c}\text { Lin } \\
{\left[{ }^{\circ}\right]}\end{array}$ & $\begin{array}{c}\text { Depth } \\
{[\mathrm{km}]}\end{array}$ & $\begin{array}{c}\text { Strike } \\
{\left[{ }^{\circ}\right]}\end{array}$ & $\begin{array}{c}\text { Dip } \\
{\left[{ }^{\circ}\right]}\end{array}$ & $\begin{array}{c}\text { Length } \\
{[\mathrm{km}]}\end{array}$ & $\begin{array}{c}\text { Width } \\
{[\mathrm{km}]}\end{array}$ & $\begin{array}{c}\text { Rake } \\
{\left[{ }^{\circ}\right]}\end{array}$ & $\begin{array}{c}\text { Slip } \\
{[\mathrm{m}]}\end{array}$ & Mw \\
\hline $07 / 3 / 6$ & 100,53 & $-0,65$ & 20,9 & 150 & 84 & 25,82 & 9,23 & 180 & 177 & 6,4 \\
\hline $07 / 3 / 6$ & 100,47 & $-0,51$ & 21,9 & 149 & 80 & 22,59 & 8,34 & 180 & 179 & 6,3
\end{tabular}

\subsection{Metode Pengolahan Data}

Metode pengolahan data yang digunakan untuk mengolah data GPS dan data lainnya untuk menghitung geseran koseismik gempa Sianok dilakukan seperti pada diagram alir Gambar 3. 


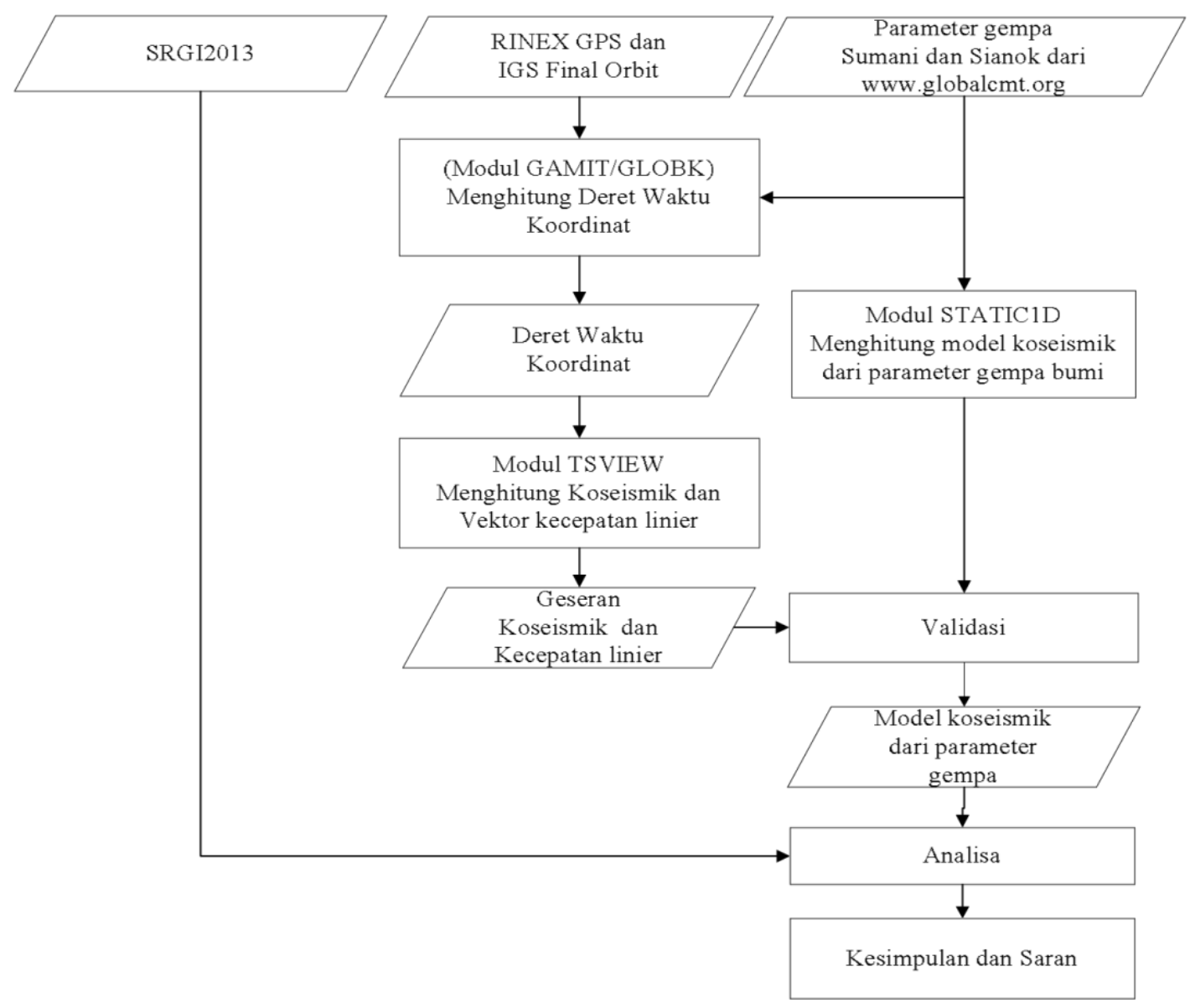

\section{Gambar 3. Diagram alir pengolahan data}

Pengolahan data dilakukan sebagai berikut:

1) Pengolahan data GPS menggunakan perangkat lunak scientific, GAMIT/GLOBK versi 10.6. Perangkat lunak tersebut terdiri atas dua modul, yaitu: modul GAMIT untuk menghitung parameter vektor baseline dan modul GLOBK untuk perataan vektor baseline hingga diperoleh nilai koordinat akhir. Untuk data GPS episodik dapat dihasilkan koordinat deret waktu. Beberapa ketentuan yang digunakan dalam pengolahan data GPS deret waktu koordinat adalah sebagai berikut:

a. Menerapkan koreksi refraksi ionosfer dan multipath, serta menggunakan orbit teliti IGS final dan model koreksi absolut pusat fase antena, baik antena satelit maupun receiver.

b. Menerapkan model Solid Earth Tide (IERS 2003), Ocean Tide Loading (FES 2004), dan global troposphere mapping function (GMF).

c. Pengikatan titik kontrol ke jaring kerangka referensi global ITRF 2008 epok 2005.

d. Hasil akhir setelah melalui modul GLOBK adalah berupa deret waktu koordinat semua titik GPS yang terdefinisi dalam ITRF 2008.

e. Menghitung kecepatan (velocity rate) dan koseismik menggunakan modul TSVIEW.

2) Berikutnya dari data deret waktu dihitung koseismik dan vektor kecepatan linear menggunakan software TSVIEW. 
3) Selanjutnya menghitung model koseismik gempabumi Sumani dan Sianok berdasarkan data parameter gempabumi dari Global Centroid Moment Tensor (CMT) (Ekström dkk., 2012), menggunakan perangkat lunak STATIC 1D, dilakukan secara berulang dengan melakukan modifikasi lokasi pusat gempa sehingga mendekati besaran koseismik dari pengamatan GPS.

4) Validasi model koseismik hasil hitungan dari data parameter gempabumi Global CMT menggunakan koseismik dari hitungan data GPS.

5) Terakhir dilakukan analisis geseran koseismik gempa sianok terhadap SRGI 2013.

6) Dari hasil analisis yang diperoleh, kemudian ditarik kesimpulan beserta saran atau rekomendasi untuk penelitian selanjutnya.

\section{HASIL DAN PEMBAHASAN}

Hasil dan analisis dari setiap tahapan penelitian yang meliputi hasil dan analisis dari deret waktu koordinat dari solusi survei tahunan, hasil dan analisis vektor kecepatan linear, dan hasil analisis estimasi pemodelan koseismik gempa Sianok tahun 2007.

\subsection{Deret Waktu Koordinat Tahunan}

Proses pengolahan data hasil pengamatan GPS menggunakan perangkat lunak GAMIT/GLOBK 10.6 menghasilkan deret waktu koordinat tahunan setiap titik pengamatan. Deret waktu harian ditampilkan dalam komponen pergerakan timur-barat, utara-selatan, dan vertikal pada 11 titik pengamatan GPS berkala dari tahun 1993 sampai 2007. Komponen tersebut akan menyatakan arah pergerakan titik pengamatan secara horizontal dan vertikal. Salah satu deret waktu koordinat berkala tahunan tersebut dapat dilihat pada Gambar 4.
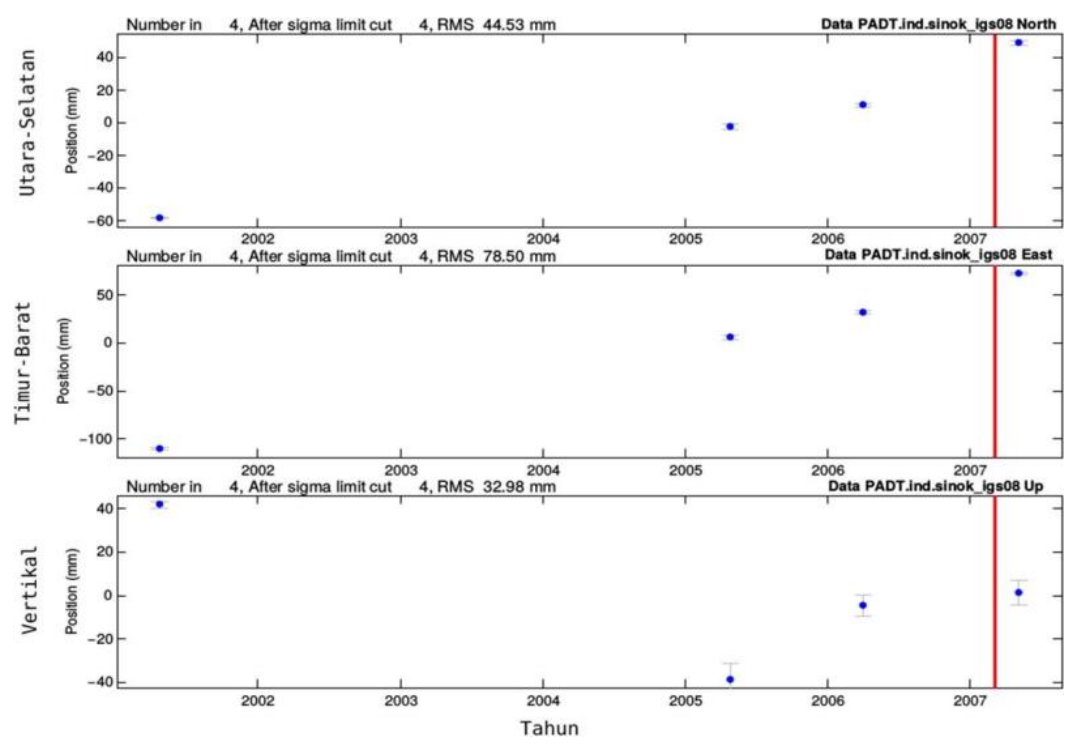

Gambar 4. Deret waktu koordinat harian titik PADT - garis vertikal merah merupakan waktu terjadinya gempabumi Sianok 6 Maret 2007

Deret waktu koordinat tahunan titik GPS mendeskripsikan adanya pola perubahan koordinat baik dalam komponen horizontal maupun komponen vertikal. Dari data deret waktu koordinat berkala ini, kemudian diestimasi vektor kecepatan linear dengan menggunakan persamaan (2). 


\subsection{Vektor Kecepatan Linear Stasiun GPS}

Nilai kecepatan pergerakan titik pengamatan yang mengacu kepada ITRF 2008 merupakan hasil perhitungan kecepatan berdasarkan perpindahan koordinat masing-masing titik pengamatan dari tahun ke tahun. Arah pergerakan dari masing-masing titik dapat dilihat pada Gambar 5.

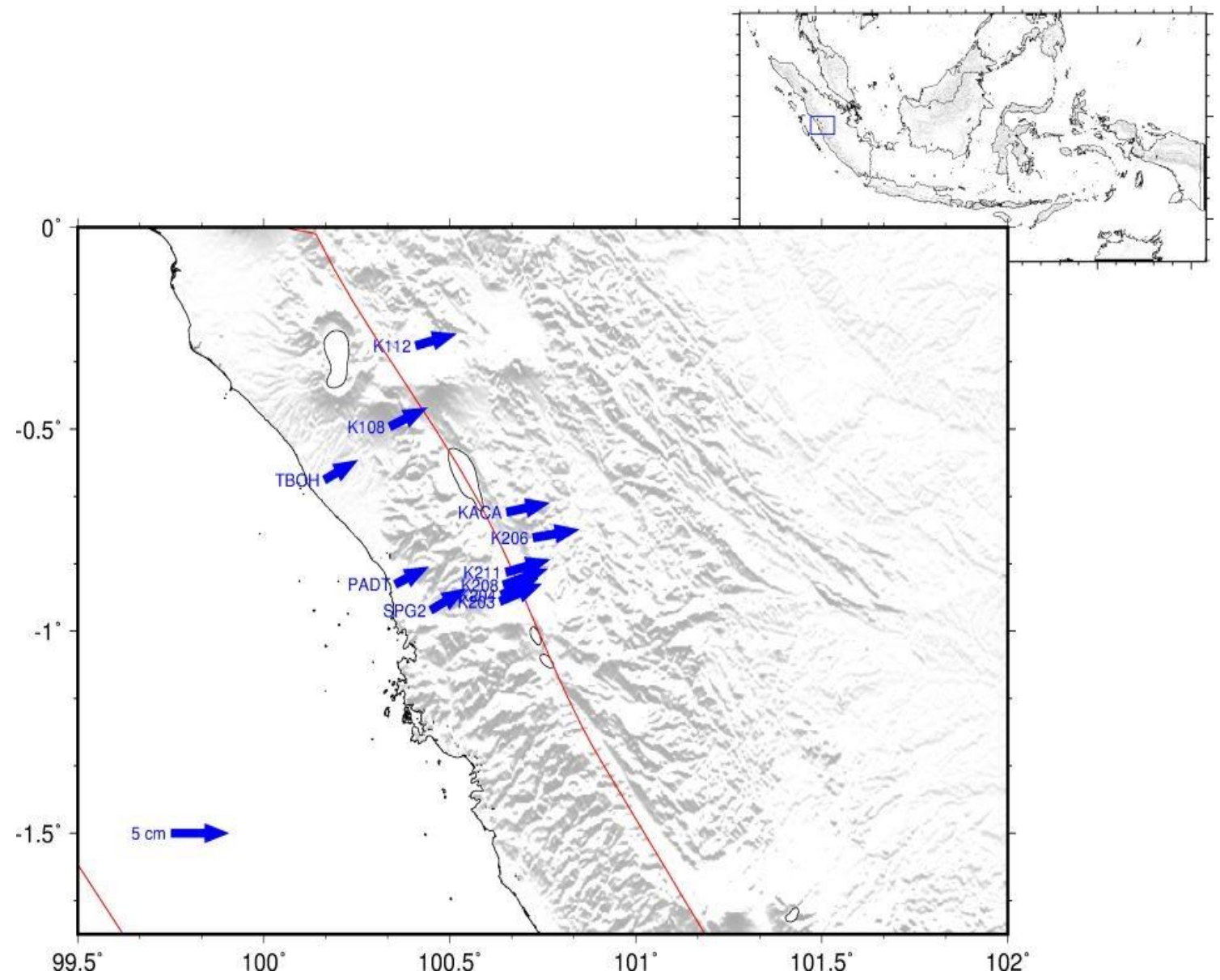

Gambar 5. Vektor Kecepatan linear titik pengamatan GPS mengacu pada ITRF 2008

Gambar 5 merupakan pola vektor kecepatan linear titik GPS berkala dalam kerangka koordinat global ITRF 2008. Pola vektor kecepatan linear menuju ke arah timur laut. Rerata kecepatan linear titik GPS di sebelah barat patahan Sumatra (TBOH, PADT, SPG2, K108, K211, K208, K204, K203) sebesar 36,02 mm/tahun dan rerata kecepatan linear titik GPS di sebelah timur patahan Sumatra (K112, KACA, K206) sebesar 38,25 mm/tahun. Perbedaan besar kecepatan linear antara titik di sebelah barat dan timur patahan Sumatra mengindikasikan eksistensi dari patahan Sumatra.

\subsection{Estimasi Kosesimik dari Data GPS}

Estimasi koseismik dari data GPS dilakukan bersamaan dengan tahapan estimasi vektor kecepatan linear stasiun GPS. Sebagai data tambahan adalah waktu terjadinya gempabumi Sianok 2007. Koseismik yang dihasilkan dari deret waktu koordinat GPS merupakan koseismik dari dua gempabumi yang terjadi pada tanggal 6 Maret 2007. Hasil koseismik untuk masingmasing titik GPS dapat dilihat pada Gambar 6 dan Tabel 4. 
Tabel 4. Pergeseran koseismik gempabumi Sianok dari deret waktu koordinat titik GPS

\begin{tabular}{ccccccccc}
\hline $\begin{array}{c}\text { Nama } \\
\text { Stasiun }\end{array}$ & $\begin{array}{c}\text { Bujur } \\
\left({ }^{\circ}\right)\end{array}$ & $\begin{array}{c}\text { Lintang } \\
\left({ }^{\circ}\right)\end{array}$ & $\begin{array}{c}\text { Timur- } \\
\text { Barat } \\
(\mathrm{mm})\end{array}$ & $\begin{array}{c}\text { Utara- } \\
\text { Selatan } \\
(\mathrm{mm})\end{array}$ & $\begin{array}{c}\text { Simur- } \\
\text { Barat } \\
(\mathrm{mm})\end{array}$ & $\begin{array}{c}\text { Sd. } \\
\text { Selatan } \\
(\mathrm{mm})\end{array}$ & $\begin{array}{c}\text { Tinggi } \\
(\mathrm{mm})\end{array}$ & $\begin{array}{c}\text { Singgi } \\
(\mathrm{mm})\end{array}$ \\
\hline K108 & 100,3384 & $-0,4939$ & $-75,39$ & 38,70 & 8,17 & 6,90 & 67,68 & 30,06 \\
\hline K112 & 100,4080 & $-0,2934$ & $-2,79$ & $-21,70$ & 15,02 & 9,29 & 1,15 & 44,16 \\
\hline K203 & 100,6345 & $-0,9265$ & $-21,53$ & 15,07 & 5,36 & 4,25 & 58,09 & 18,54 \\
\hline K204 & 100,6377 & $-0,9108$ & 10,35 & 25,04 & 11,62 & 8,66 & $-29,62$ & 39,06 \\
\hline K206 & 100,7237 & $-0,7689$ & 52,06 & $-9,06$ & 10,25 & 7,84 & 81,91 & 44,05 \\
\hline K208 & 100,6436 & $-0,8859$ & $-20,79$ & 23,69 & 11,48 & 7,65 & 68,16 & 42,53 \\
\hline K211 & 100,6506 & $-0,8543$ & 2,31 & 20,74 & 9,66 & 6,79 & 78,37 & 38,54 \\
\hline KACA & 100,6523 & $-0,7055$ & 130,02 & $-37,91$ & 10,33 & 7,41 & 53,05 & 28,81 \\
\hline PADT & 100,3531 & $-0,8843$ & 8,95 & 23,00 & 2,46 & 1,85 & 31,58 & 7,86 \\
\hline SPG2 & 100,4487 & $-0,9483$ & $-6,09$ & 26,82 & 4,44 & 3,36 & $-11,84$ & 15,19 \\
\hline TBOH & 100,1628 & $-0,6256$ & $-17,68$ & $-6,82$ & 2,37 & 1,72 & 13,97 & 7,13 \\
\hline & & & & & & & & \\
\hline
\end{tabular}

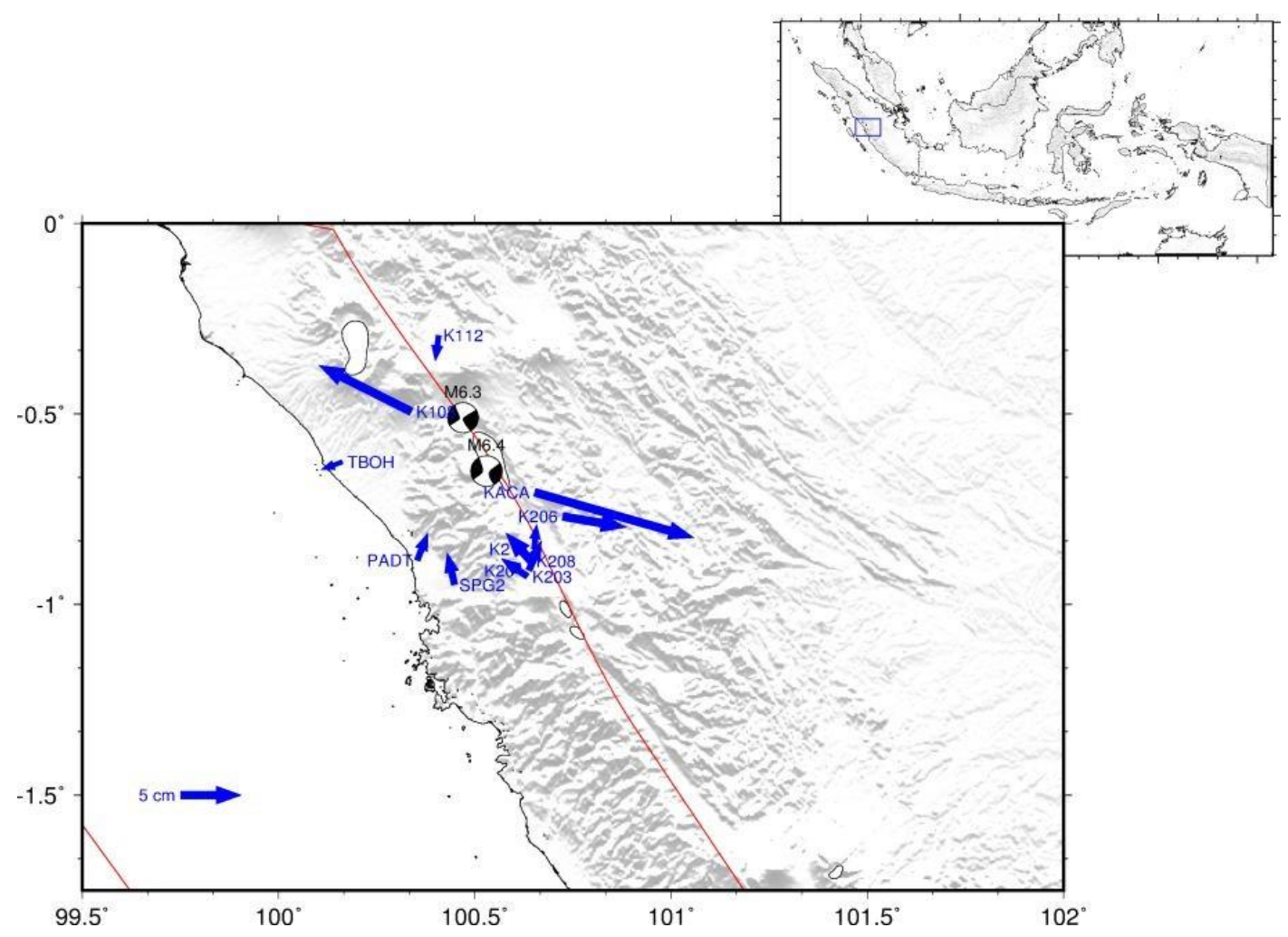

Gambar 6. Pergeseran Koseismik Gempa Sianok dari deret waktu koordinat titik GPS garis merah merupakan deliniasi patahan Sumatra 


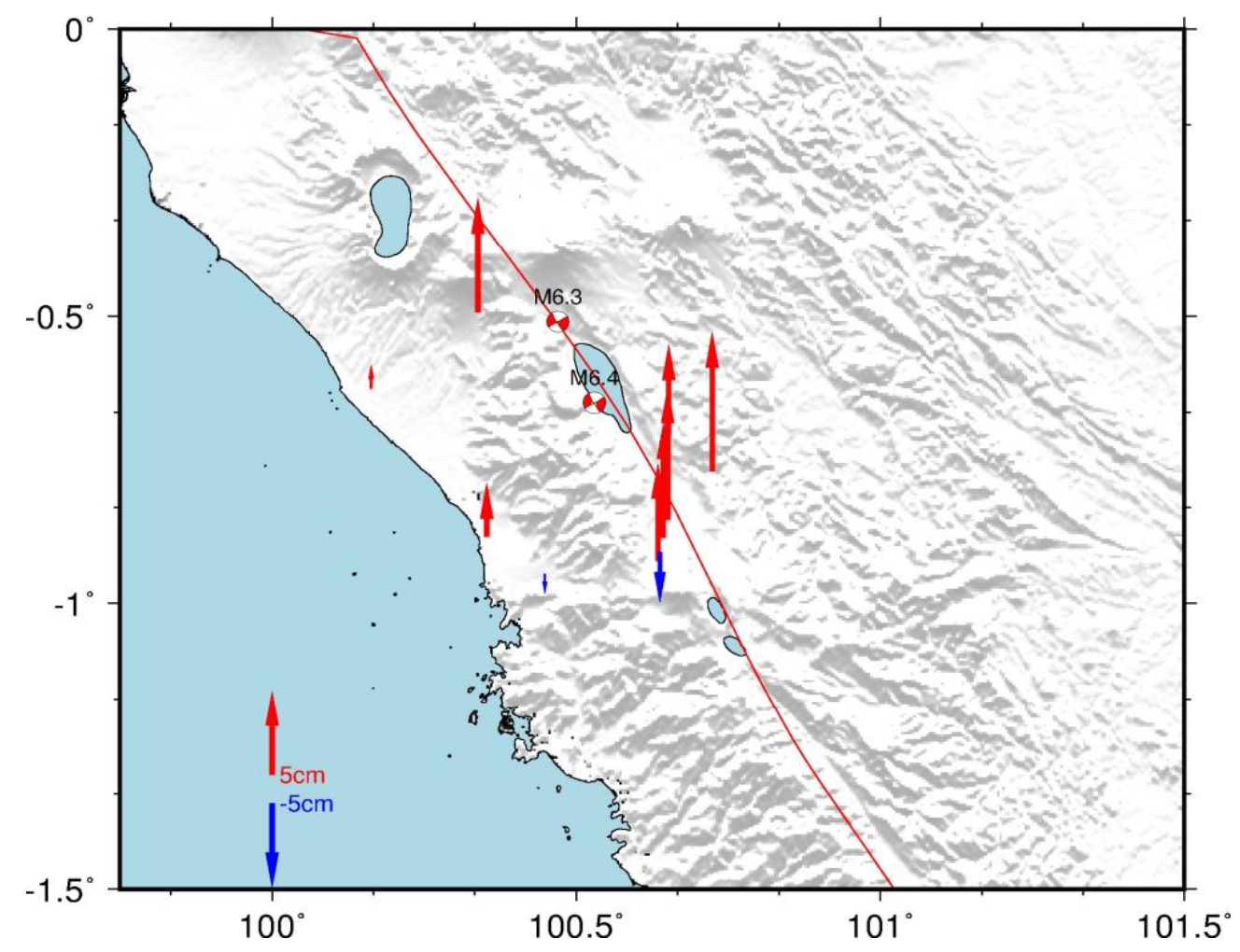

\section{Gambar 7. Pergeseran Koseismik Gempa Sianok kearah vertikal dari deret waktu koordinat titik GPS - garis merah merupakan deliniasi patahan Sumatra}

Secara umum, pola kosesimik gempabumi Sianok mendeskripsikan mekanisme gempabumi pada sesar geser sesuai dengan mekanisme gempabumi sesar Sianok, yaitu gempabumi sesar geser. Nilai kosesimik terbesar terjadi pada titik KACA dan K108, yaitu 135,43 mm dan 84,74 $\mathrm{mm}$. Besarnya nilai koseismik kedua titik tersebut terjadi karena terletak paling dekat dengan sumber gempabumi.

Untuk komponen pergeseran koseismik ke arah vertikal berkisar antara 29,62 mm sampai dengan 78,37 mm. Dilihat dari presisi pergeseran kearah tinggi nilainya cukup besar sehingga informasi pergeseran kearah vertikal hanya mengindikasikan terjadi deformasi kearah vertikal.

\subsection{Pemodelan Koseismik dari Data Parameter Gempabumi}

Berdasarkan data parameter gempabumi dari www.globalcmt.org dapat dihitung geometri dari bidang sesar dan besarnya slip pada bidang sesar. Dengan menggunakan data paramater geometri bidang sesar dan perangkat lunak STATIC 1D dapat dimodelkan besarnya koseismik.

Model koseismik dihitung dengan tiga cara:

1) Model 1 (Model koseismik dihitung sesuai dengan data parameter gempabumi Sianok dan Sumani dari global CMT.

2) Model 2 (Model koseismik dihitung dengan merelokasi pusat gempa Sumani ke arah selatan sejauh $0,05^{\circ}$.

3) Model 3 (Model koseismik dihitung merelokasi pusat gempa Sumani ke arah selatan sejauh $0,1^{\circ}$.

4) Model 4 (Model koseismik dihitung merelokasi pusat gempa Sumani ke arah selatan sejauh $0,2^{\circ}$.

5) Model 5 (Model koseismik dihitung merelokasi pusat gempa Sumani ke arah selatan sejauh $0,5^{\circ}$. 
6) Model 6 (Model koseismik dihitung merelokasi pusat gempa Sumani dan Sianok ke arah utara sejauh $0,05^{\circ}$.

Hasil dari keenam model divalidasi dengan koseismik dari hasil hitungan pengamatan GPS. Hasil validasi dapat dilihat pada Tabel 6 dan Gambar 8.

Tabel 5. Pergeseran koseismik gempa Sianok dari data GPS dan parameter gempabumi

\begin{tabular}{|c|c|c|c|c|c|c|c|c|c|c|c|c|c|c|c|c|}
\hline \multirow[t]{2}{*}{ Stasiun } & \multirow[t]{2}{*}{$\begin{array}{c}\text { Bujur } \\
\left({ }^{\circ}\right)\end{array}$} & \multirow[t]{2}{*}{$\begin{array}{l}\text { Lintang } \\
\left({ }^{\circ}\right)\end{array}$} & \multicolumn{2}{|c|}{$\begin{array}{l}\text { Koseismik } \\
\text { GPS (mm) }\end{array}$} & \multicolumn{2}{|c|}{$\begin{array}{l}\text { Koseismik } \\
\text { Model } 1 \\
(\mathrm{~mm})\end{array}$} & \multicolumn{2}{|c|}{$\begin{array}{l}\text { Koseismik } \\
\text { Model } 2 \\
(\mathrm{~mm})\end{array}$} & \multicolumn{2}{|c|}{$\begin{array}{l}\text { Koseismik } \\
\text { Model } 3 \\
(\mathbf{m m})\end{array}$} & \multicolumn{2}{|c|}{$\begin{array}{c}\text { Koseismik } \\
\text { Model } 4 \\
(\mathrm{~mm})\end{array}$} & \multicolumn{2}{|c|}{$\begin{array}{l}\text { Koseismik } \\
\text { Model } 5 \\
(\mathrm{~mm})\end{array}$} & \multicolumn{2}{|c|}{$\begin{array}{l}\text { Koseismik } \\
\text { Model } 6 \\
(\mathrm{~mm})\end{array}$} \\
\hline & & & T-B & U-S & T-B & U-S & T-B & U-S & T-B & U-S & T-B & U-S & T-B & U-S & T-B & U-S \\
\hline K108 & 100,3384 & $-0,4939$ & $-75,4$ & 38,7 & $-21,6$ & 9,7 & $-19,5$ & 9,6 & $-17,1$ & 9,1 & $-13,2$ & 7,3 & $-9,9$ & 4,6 & $-20,7$ & 10,1 \\
\hline K112 & 100,4080 & $-0,2934$ & $-2,8$ & $-21,7$ & $-3,7$ & $-6,8$ & $-3,4$ & $-5,8$ & $-3,4$ & $-5,1$ & $-3,7$ & $-4,2$ & $-3,3$ & $-3,2$ & $-4,7$ & $-8,1$ \\
\hline K203 & 100,6345 & $-0,9265$ & $-21,5$ & 15,1 & 0,7 & 12,6 & 1,7 & 14,3 & 2,5 & 15,2 & 1,2 & 13,8 & $-11,4$ & 7,1 & 0,1 & 10,1 \\
\hline K204 & 100,6377 & $-0,9108$ & 10,4 & 25,0 & 1,1 & 12,1 & 2,2 & 13,5 & 2,8 & 14,2 & 1,0 & 12,4 & $-10,3$ & 6,4 & 0,4 & 9,7 \\
\hline K206 & 100,7237 & $-0,7689$ & 52,1 & $-9,1$ & 13,4 & $-3,5$ & 13,3 & $-3,4$ & 11,9 & $-3,8$ & 5,9 & $-6,7$ & 1,4 & $-9,1$ & 11,9 & $-3,7$ \\
\hline K208 & 100,6436 & $-0,8859$ & $-20,8$ & 23,7 & 2,1 & 10,8 & 3,1 & 11,8 & 3,5 & 12,1 & 0,9 & 9,9 & $-8,4$ & 4,9 & 1,2 & 8,7 \\
\hline K211 & 100,6506 & $-0,8543$ & 2,3 & 20,7 & 3,7 & 8,7 & 4,5 & 9,4 & 4,5 & 9,3 & 0,8 & 6,7 & $-6,0$ & 2,9 & 2,6 & 7,1 \\
\hline KACA & 100,6523 & $-0,7055$ & 130,0 & $-37,9$ & 11,1 & $-0,2$ & 8,9 & $-1,2$ & 5,9 & $-2,8$ & 0,5 & $-6,2$ & 2,4 & $-3,0$ & 11,5 & $-0,1$ \\
\hline PADT & 100,3531 & $-0,8843$ & 9,0 & 23,0 & 7,1 & 20,1 & 4,6 & 17,3 & 0,9 & 14,5 & $-7,5$ & 10,9 & $-6,4$ & 12,2 & 7,5 & 21,5 \\
\hline SPG2 & 100,4487 & $-0,9483$ & $-6,1$ & 26,8 & 5,4 & 24,1 & 5,8 & 23,7 & 4,8 & 21,9 & $-1,8$ & 15,9 & $-13,4$ & 12,5 & 4,1 & 22,1 \\
\hline $\mathrm{TBOH}$ & 100,1628 & $-0,6256$ & $-17,7$ & $-6,8$ & $-17,0$ & 2,2 & 16,6 & 2,9 & $-15,4$ & 3,4 & $-12,2$ & 3,4 & $-6,9$ & 1,9 & $-14,4$ & 2,4 \\
\hline
\end{tabular}

Tabel 6. Selisih pergeseran koseismik gempa Sianok dari data parameter gempabumi hasil pemodelan dibandingkan dengan koseismik dari pengamatan GPS

\begin{tabular}{|c|c|c|c|c|c|c|c|c|c|c|c|c|c|c|}
\hline \multirow[t]{2}{*}{ Stasiun } & \multirow[t]{2}{*}{$\begin{array}{c}\text { Bujur } \\
\left({ }^{\circ}\right)\end{array}$} & \multirow[t]{2}{*}{$\begin{array}{c}\text { Lintang } \\
\left({ }^{\circ}\right)\end{array}$} & \multicolumn{2}{|c|}{$\begin{array}{c}\text { Selisih } \\
\text { Koseismik } \\
\text { GPS - Model } \\
1(\mathbf{m m})\end{array}$} & \multicolumn{2}{|c|}{$\begin{array}{c}\text { Selisih } \\
\text { Koseismik } \\
\text { GPS - Model } \\
2(\mathbf{m m})\end{array}$} & \multicolumn{2}{|c|}{$\begin{array}{c}\text { Selisih } \\
\text { Koseismik } \\
\text { GPS - Model } \\
3(\mathrm{~mm})\end{array}$} & \multicolumn{2}{|c|}{$\begin{array}{c}\text { Selisih } \\
\text { Koseismik } \\
\text { GPS - Model } \\
4(\mathrm{~mm})\end{array}$} & \multicolumn{2}{|c|}{$\begin{array}{c}\text { Selisih } \\
\text { Koseismik } \\
\text { GPS - Model } \\
5(\mathrm{~mm})\end{array}$} & \multicolumn{2}{|c|}{$\begin{array}{c}\text { Selisih } \\
\text { Koseismik } \\
\text { GPS - Model } \\
6(\mathrm{~mm})\end{array}$} \\
\hline & & & T-B & U-S & T-B & U-S & T-B & U-S & T-B & U-S & T-B & U-S & T-B & U-S \\
\hline K108 & 100,3384 & $-0,4939$ & $-53,8$ & 29,0 & $-55,9$ & 29,1 & $-58,3$ & 29,6 & $-62,2$ & 31,4 & -65.5 & 34,1 & $-54,7$ & 28,6 \\
\hline K112 & 100,4080 & $-0,2934$ & 0,9 & $-14,9$ & 0,6 & $-15,9$ & 0,6 & $-16,6$ & 0,9 & $-17,5$ & 0,5 & $-18,5$ & 1,9 & $-13,6$ \\
\hline K203 & 100,6345 & $-0,9265$ & $-22,2$ & 2,4 & $-23,2$ & 0,8 & $-24,0$ & $-0,1$ & $-22,8$ & 1,3 & $-10,1$ & 8,0 & $-21,6$ & 5,0 \\
\hline K204 & 100,6377 & $-0,9108$ & 9,2 & 13,0 & 8,2 & 11,5 & 7,5 & 10,9 & 9,3 & 12,7 & 20,6 & 18,7 & 9,9 & 15,3 \\
\hline K206 & 100,7237 & $-0,7689$ & 38,7 & $-5,6$ & 38,7 & $-5,7$ & 40,2 & $-5,3$ & 46,1 & $-2,4$ & 50,6 & 0,0 & 40,2 & $-5,4$ \\
\hline K208 & 100,6436 & $-0,8859$ & $-22,9$ & 12,9 & $-23,9$ & 11,9 & $-24,3$ & 11,6 & $-21,7$ & 13,8 & $-12,4$ & 18,7 & $-22,0$ & 15,0 \\
\hline K211 & 100,6506 & $-0,8543$ & $-1,4$ & 12,0 & $-2,2$ & 11,4 & $-2,2$ & 11,5 & 1,5 & 14,1 & 8,3 & 17,8 & $-0,3$ & 13,7 \\
\hline KACA & 100,6523 & $-0,7055$ & 118,9 & $-37,7$ & 121,1 & $-36,7$ & 124,1 & $-35,1$ & 129,5 & $-31,7$ & 127,6 & $-35,0$ & 118,5 & $-37,8$ \\
\hline PADT & 100,3531 & $-0,8843$ & 1,9 & 2,9 & 4,3 & 5,7 & 8,1 & 8,5 & 16,5 & 12,1 & 15,3 & 10,8 & 1,4 & 1,5 \\
\hline SPG2 & 100,4487 & $-0,9483$ & $-11,5$ & 2,7 & $-11,9$ & 3,1 & $-10,9$ & 4,9 & $-4,3$ & 10,9 & 7,4 & 14,3 & $-10,1$ & 4,7 \\
\hline \multirow[t]{3}{*}{$\mathrm{TBOH}$} & 100,1628 & $-0,6256$ & $-0,6$ & $-9,1$ & $-1,0$ & $-9,7$ & $-2,3$ & $-10,2$ & $-5,5$ & $-10,2$ & $-10,8$ & $-8,7$ & $-3,3$ & $-9,2$ \\
\hline & \multicolumn{2}{|c|}{ Standar Deviasi } & $\pm 44,1$ & $\pm 17,6$ & $\pm 45,1$ & $\pm 17,4$ & $\pm 46,4$ & $\pm 17,3$ & $\pm 48,4$ & $\pm 17,6$ & $\pm 47,7$ & $\pm 19,7$ & $\pm 44,1$ & $\pm 17,9$ \\
\hline & \multicolumn{2}{|c|}{ Residual Misfit } & \multicolumn{2}{|c|}{ $\pm 47,5$} & \multicolumn{2}{|c|}{ $\pm 48,3$} & \multicolumn{2}{|c|}{ $\pm 49,5$} & \multicolumn{2}{|c|}{ $\pm 51,6$} & \multicolumn{2}{|c|}{ $\pm 51,6$} & \multicolumn{2}{|c|}{ $\pm 47,6$} \\
\hline
\end{tabular}




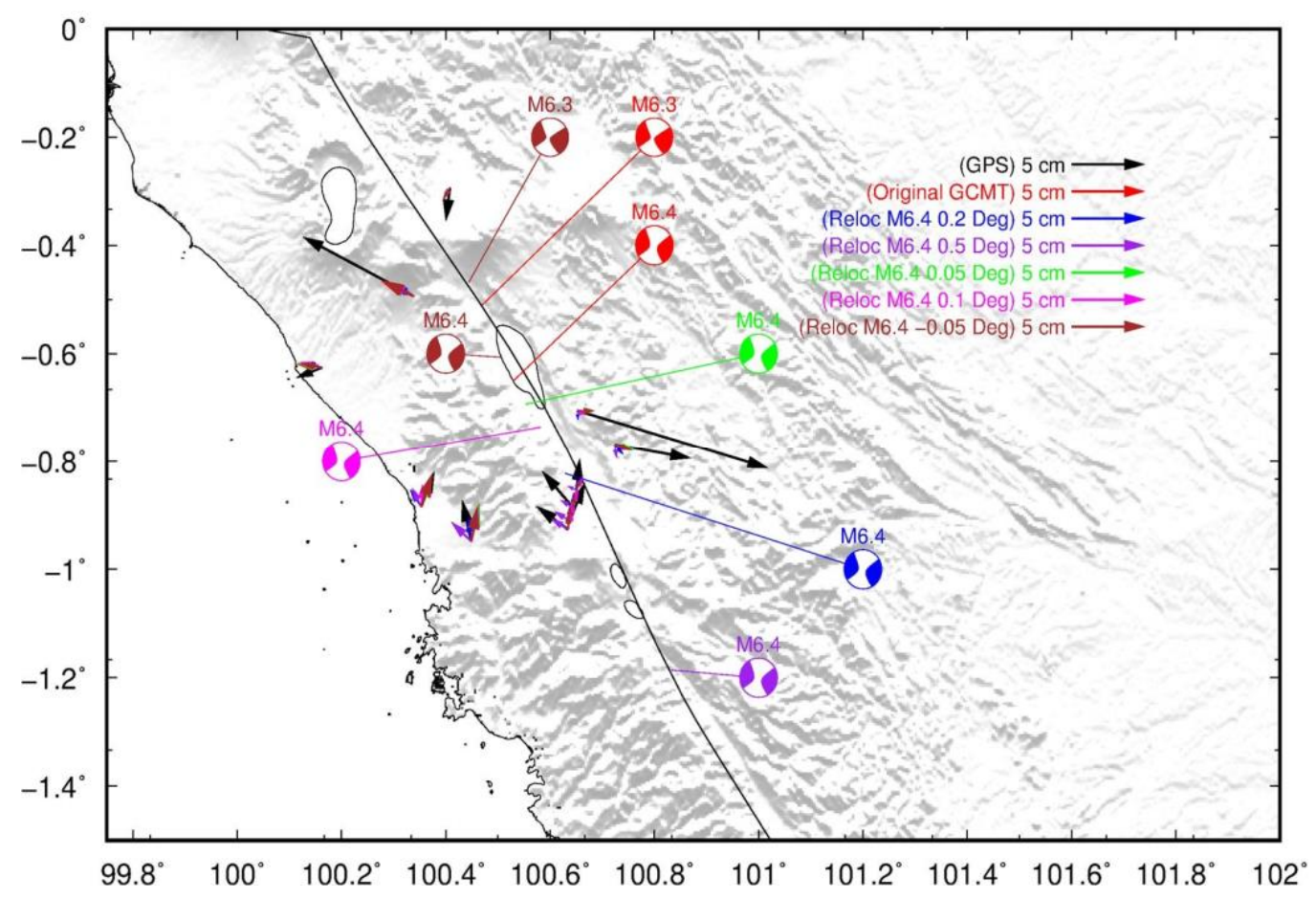

Gambar 8. Koseismik hasil pemodelan dibandingkan dengan koseismik dari pengamatan GPS

Dari Tabel 6 dan Gambar 8, didapat deviasi standar residual pengurangan koseismik model dengan koseismik dari GPS yang terkecil adalah sebesar $44,1 \mathrm{~mm}$ ke arah barat-timur dan $17,6 \mathrm{~mm}$ ke arah utara-selatan. Beberapa faktor yang menyebabkan besarnya nilai residual dan misfit adalah kurangnya data pengamatan GPS setelah terjadinya gempabumi dan informasi geometri gempabumi dari global CMT untuk gempabumi Sianok dan Sumani ketersediaan data kurang lengkap.

Berdasarkan model 1 dibuat model deformasi koseismik gempabumi Sianok seperti pada Gambar 9 dan Gambar 10 berikut. 


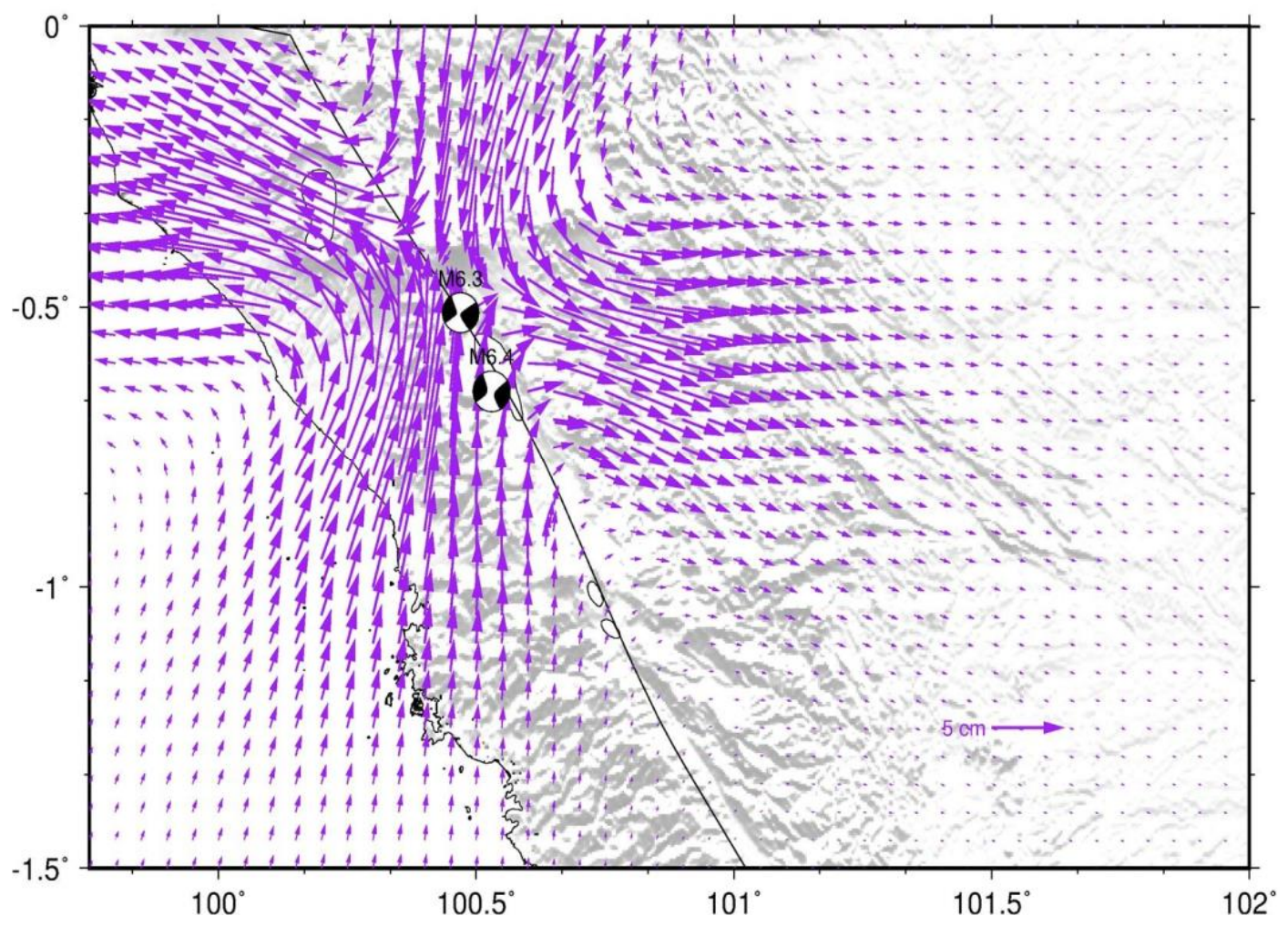

Gambar 9. Model koseismik gempabumi Sianok

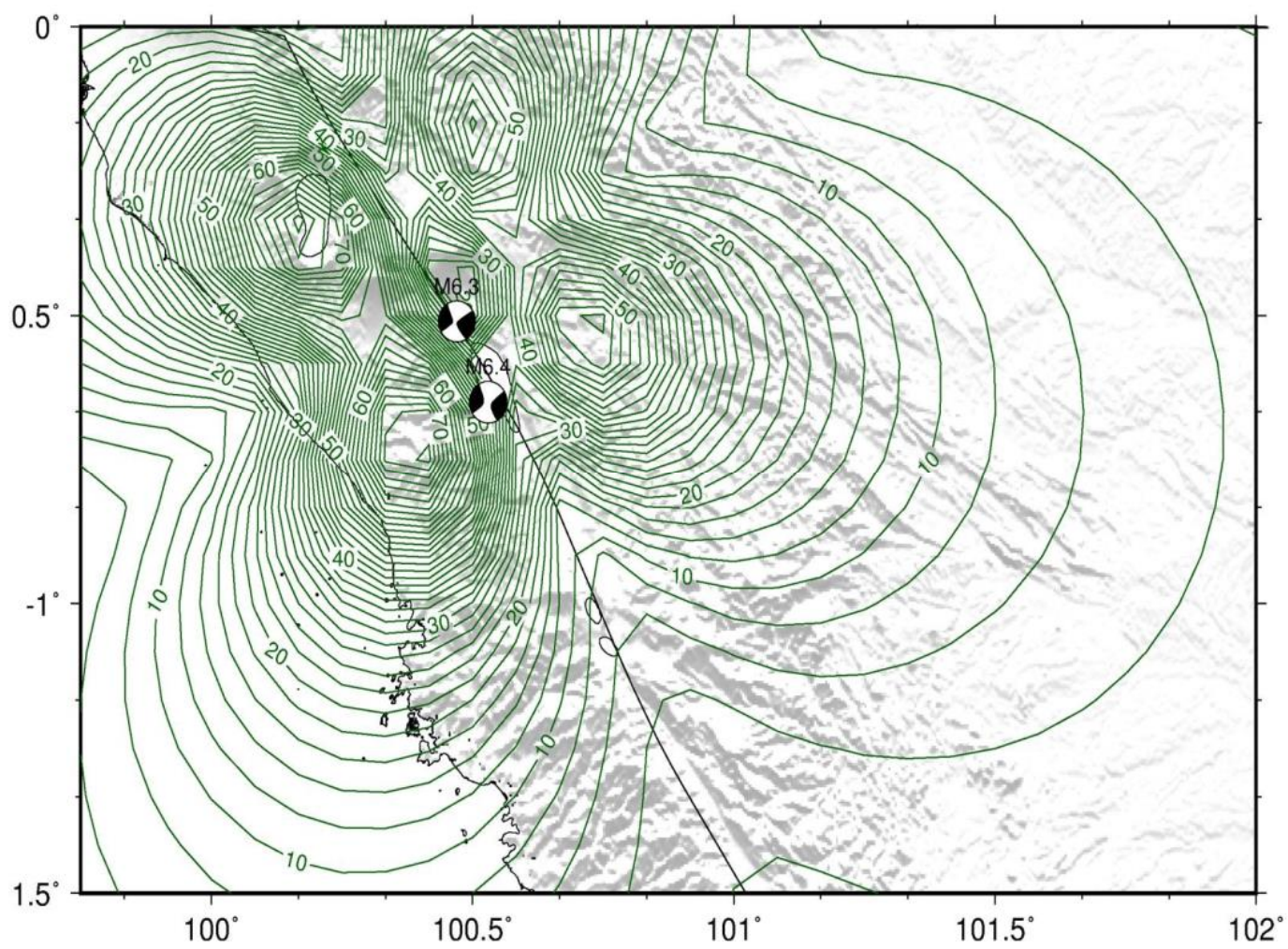

Gambar 10. Model kontur koseismik gempabumi Sianok 


\subsection{Pengaruh Pergeseran Koseismik Gempa Sianok terhadap SRGI 2013}

Pengaruh pergeseran koseismik gempabumi Sianok terhadap Sistem Referensi Geospasial Indonesia 2013 (SRGI 2013) dapat dilihat pengaruhnya terhadap jaring kontrol geodesi dan peta dasar nasional.

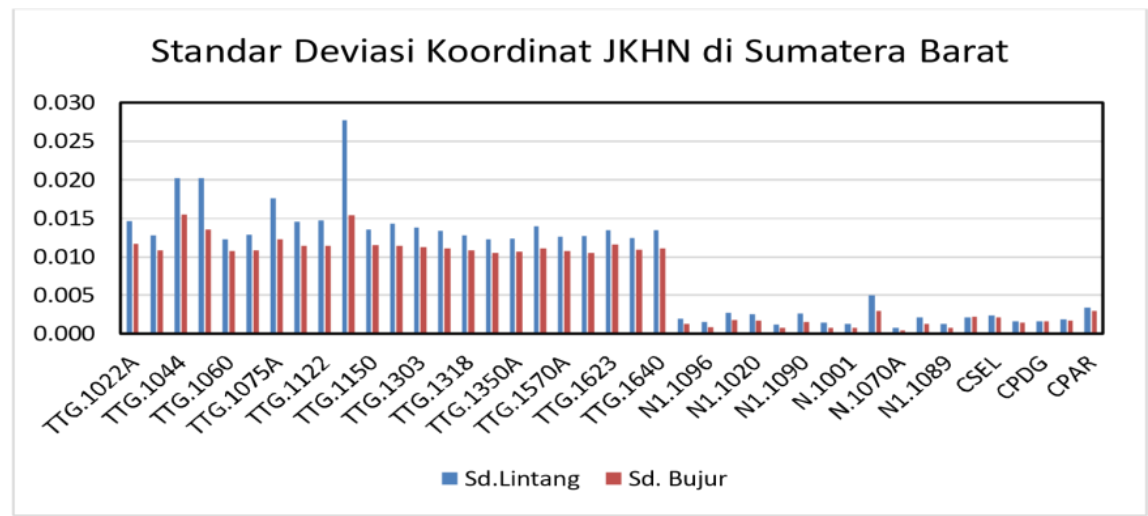

\section{Gambar 11. Grafik deviasi standar koordinat JKHN di Sumbar}

Besarnya koseismik gempabumi Sianok dari pengamatan GPS berkisar antara -75,4 sampai dengan 130,0 mm ke arah timur-barat dan berkisar antara -37,9 sampai dengan 38,7 mm ke arah utara-selatan. Jika dibandingkan dengan deviasi standar titik jaring kontrol horizontal di Sumatera Barat yang besarnya lebih kecil dari $30 \mathrm{~mm}$ (timur-barat maupun utara-selatan) maka dapat diindikasikan bahwa pergeseran koseismik gempa Sianok berpengaruh terhadap koordinat jaring kontrol horizontal. Dari model koseismik gempa Sianok dapat dilihat pengaruhnya pada titik jaring kontrol horizontal seperti pada Gambar 12.

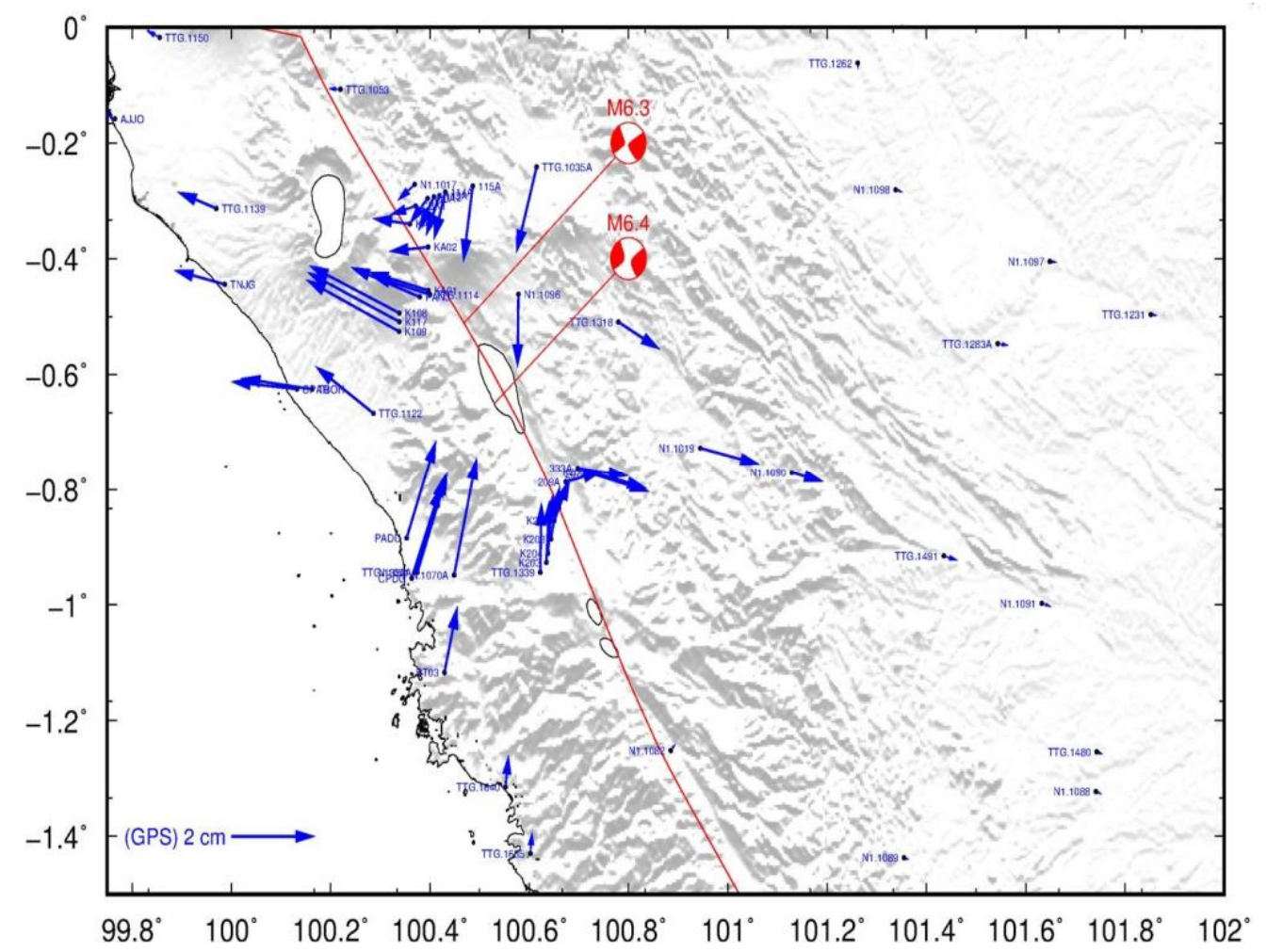

Gambar 12. Besar koseismik gempabumi Sianok terhadap JKHN di Sumbar 
Pengaruh pergeseran koseismik gempa Sianok terhadap peta seperti pada Tabel 7.

Tabel 7. Pengaruh pergeseran koseismik gempa Sianok pada peta skala1 : 1000

\begin{tabular}{lccccc}
\hline $\begin{array}{c}\text { Nama } \\
\text { Stasiun }\end{array}$ & Bujur $\left(^{\circ}\right)$ & $\begin{array}{c}\text { Lintang } \\
\left({ }^{\circ}\right)\end{array}$ & $\begin{array}{c}\text { Pergeseran } \\
\text { Komponen } \\
\text { horizontal } \\
(\mathrm{mm})\end{array}$ & $\begin{array}{c}\text { Pergeseran } \\
\text { Komponen } \\
\text { Tinggi } \\
(\mathrm{mm})\end{array}$ & $\begin{array}{c}\text { Ketelitian peta skala } \\
1: 1000 \\
\text { Horizontal/Vertikal } \\
0,2 \times \text { skala }\end{array}$ \\
\hline K108 & 100,3384 & $-0,4939$ & 84,8 & 67,68 & $200 \mathrm{~mm}$ \\
\hline K112 & 100,4080 & $-0,2934$ & 21,9 & 1,15 & \\
\hline K203 & 100,6345 & $-0,9265$ & 26,3 & 58,09 & \\
\hline K204 & 100,6377 & $-0,9108$ & 27,1 & $-29,62$ \\
\hline K206 & 100,7237 & $-0,7689$ & 52,9 & 81,91 & \\
\hline K208 & 100,6436 & $-0,8859$ & 31,5 & 68,16 & \\
\hline K211 & 100,6506 & $-0,8543$ & 20,8 & 78,37 & \\
\hline KACA & 100,6523 & $-0,7055$ & 135,4 & 53,05 & \\
\hline PADT & 100,3531 & $-0,8843$ & 24,7 & 31,58 & \\
\hline SPG2 & 100,4487 & $-0,9483$ & 27,5 & $-11,84$ & \\
\hline TBOH & 100,1628 & $-0,6256$ & 19,0 & 13,97 & \\
\hline
\end{tabular}

Pergeseran koseismik gempa Sianok dengan kisaran 19,0 mm sampai dengan 135,4 mm tidak berpengaruh terhadap peta skala $1: 1000$ karena besarnya koseismik lebih kecil dari ketelitian peta 1 : 1000 sebesar $200 \mathrm{~mm}$.

\section{KESIMPULAN DAN SARAN}

\subsection{Kesimpulan}

Berdasarkan data yang tersedia, model deformasi koseismik yang sesuai untuk gempabumi Sianok adalah model deformasi koseismik yang dihitung berdasarkan data parameter gempabumi dari global CMT, yang sudah divalidasi dengan data koseismik dari pengamatan GPS. Adapun berdasarkan ketersediaan data yang digunakan, dihasilkan model deformasi koseismik paling optimal dengan standar deviasi nilai residual $\pm 44.1 \mathrm{~mm}$ ke arah timur-barat dan $\pm 17,6 \mathrm{~mm}$ ke arah utara-selatan. Pergeseran koseismik gempa Sianok perlu diperhitungkan dalam penggunaan titik jaring kontrol horizontal sebagai referensi pengukuran penentuan posisi di lapangan. Besarnya koseismik gempabumi Sianok tidak kelihatan pengaruhnya terhadap peta rupabumi skala 1:1000.

\subsection{Saran}

Saran yang dapat diberikan berdasarkan hasil penelitian yang diperoleh adalah sebagai berikut: a. Diperlukan pemanfaatan data seismik untuk menentukan geometri bidang gempa; b. Diperlukan tambahan data pengamatan GPS sebelum dan sesudah gempabumi; dan c. Perlunya pemeliharaan jaring kontrol geodesi nasional dengan melakukan pengukuran rutin secara berkala.

\section{DAFTAR PUSTAKA}

Abidin, H. Z. (2011). Survei dengan GPS (Cetakan Ketiga). Bandung: Penerbit ITB. 
Badan Informasi Geospasial (2013). Peraturan Kepala Badan Informasi Geospasial No. 15 Tahun 2013. Badan Informasi Geospasial. Cibinong.

Dziewonski, A. dan Anderson, D. (1981). Preliminary reference Earth model (PREM). Physics of the Earth and Planetary Interiors, 25, 297-356, doi: 10.1016/0031-9201(81)90046-7.

Ekström, G., Nettles, M., dan Dziewonski, A.M. (2012). The global CMT project 2004-2010: Centroid-moment tensors for 13,017 earthquakes, Phys. Earth Planet. Inter., 200-201, 1-9, doi: 10.1016/j.pepi.2012.04.002.

Natawidjaja, D.H., Tohari, A., Subowo, E., dan Daryono, M.R. (2007). Western Sumatra Earthquakes of 6 March 2007. EERI Special Earthquake Report, pp. 5.

Nikolaidis, R.M. (2002). Observation of Geodetic and Seismic Deformation with the Global Positioning System, Disertasi, University of California, San Diego.

Pollitz, F.F. (1996). Coseismic Deformation From Earthquake Faulting On A Layered Spherical Earth. Geophysical Journal International, Volume 125, Issue 1, Pages 1-14. Dipetik dari https://doi.org/10.1111/j.1365-246X.1996.tb06530.x.

Prawirodirdjo, L., Bock, Y., McCaffrey, Genrich, J., Calais, E., Stevens, C., Puntodewo, S.S.O, Subarya, C., Rais, J., Zwick, P., dan Fauzi. (1997). Geodetic observations of interseismic strain segmentation at the Sumatra subduction zone. Geophys. Res. Lett., 24, 2601-2604, doi:10.1029/97GL52691.

Sieh, K. dan Natawidjaja, D. (2000). Neotectonics of the Sumatran fault, Indonesia. Journal of Geophysical Research: Solid Earth (1978-2012), 105(B12), 28295-28326.

Subarya, C. (2010). Pemodelan Estimasi Dinamika Pergerakan Lempeng Tektonik di Wilayah Indonesia dari Pengamatan GPS. Disertasi. Institut Teknologi Bandung, Bandung. 